\title{
The Influence of Information Technology on the Information and Service Quality for the Teaching and Learning
}

\author{
https://doi.org/10.3991/ijet.v13i12.8665
}

\author{
Lianna Sugandi, Yohannes Kurniawan $(\bowtie)$ \\ Bina Nusantara University, Jakarta, Indonesia \\ ykurniawan@binus . edu
}

\begin{abstract}
Globalization has influenced the competition paradigm of higher education institutions in the world. The situation keeps changing, depending on the economy and information technology as the backbone of business processes in organizations. Higher education institutions should have added values to win the competition. Furthermore, the awareness of the society about the importance of formal education, particularly higher education, will make colleges/universities strategic institutions generating high quality human resources. The success of colleges/universities is determined by service quality, which can be identified through the satisfaction of their customers, students and lecturers. To increase customer satisfaction and be able to compete in the globalization era, as well as generate greater profits, colleges/universities need to identify factors which influence information system services to increase customer satisfaction. Employing descriptive analysis, the study reveals that the purpose and service quality of information technology positively affect the teaching and learning process at colleges/universties.
\end{abstract}

Keywords-Teaching, Information Technology, Service Quality, Learning

\section{Introduction}

Education plays an important role in the globalization era. Competition in the education sector is increasing. Thus, each college/university needs to have added values to compete with other colleges/universities and win the competition. In order to achieve this, they have to increase the capabilities to meet the demands of the society for formal education. Higher education is a strategic sector that can generate high quality human resources. Education is an asset to increase the quality of human resources in globalization era. Therefore, it is one of the basic requirements for a nation. In order to improve its impacts and produce high quality human resources, education requires effective tools. One of the tools is information technology. Nowadays, information technology is developing very quickly. IT can improve services by providing features which can help organizations improve their business activities and increase their market share through certain strategies. Today, colleges/universities are improving their quality to meet and satisfy customers' demands. Information technology focuses on 
setting up information systems in various aspects of business activities by using computers and information technology to meet business needs in the world more quickly, timely, relevant and accurate [1]. Customer satisfaction is one factor or measure of success for any stage of the implementation of information systems in a company [2]. The image of 'good quality' basically is not based on the viewpoint or perception of the service provider. Rather, it is based on customers' viewpoint. The customers who enjoy the service in the company determine the quality of service. Customer perception of service quality is a comprehensive appraisal of the advantages of a service. Higher education institutions should anticipate the increasing competition. They should explore and enhance all aspects of education. The success factors of colleges/universities are largely determined by the quality of the services provided and strategies for delivering customer satisfaction. Colleges/universities need to achieve good customers' perceptions of service quality, because the successful factors of higher education institutions are determined by the service itself. This is the reason why all higher education institutions should make breakthroughs for improving the quality of their services. They can start by identifying factors that will support their services through information technology. In the business world, information technology has a big impact for organizations. For example, a business transaction was recorded online, real-time, and the information can be directly viewed. The organization needed to find out the problem and identify the needs of the information technology necessary to support the improvement of service quality for users.

The company has developed information systems which will improve its services [4]. According to Fathoni [3], the quality of service basically needs to be measured. The information system collects information about the performance of services for management aspects and motivation of employees. The information systems will spread information considered useful for the customers by utilizing information technology features in academic area. Then, the quality of services received by students will increase, particularly in terms of the accuracy of information, transfer of information, efficiency and time. The information system will also raise the profile of higher education institutions through communication technology, distribution and dissemination of information that can be done quickly and accurately.

The primary objective of this research is to identify factors in the service information system applications, in terms of the characteristics of the information and services quality. The results of the survey can be used as a reference for university leaders in decision making to improve the quality of operations (services). In addition, higher education institutions are able to compete in the globalization era and generate greater profits for the organization (especially private universities).

\section{Methods}

Customer satisfaction is one of the indicators of success of any development and implementation of information systems at colleges/universities. The quality of services cannot be measured based on the viewpoint or perception of service providers. It should be based on customers' viewpoint or perception. The perceptions of customers who 
enjoy the services and value/assess the quality of the services indicate their satisfaction. The concept of user satisfaction can be described in Figure 1.

Path analysis was used as a research method for quality service measurement of information systems. There are several steps to implement the measurement of service quality by using path analysis, namely: determining the variables and dimensions to be measured, and determining variables to be measured for the quality of the information system using regression methods: (1) the independent variables $(\mathrm{Xn})=$ quality of service (X1), the quality of information (X2). (2) The dependent variable (Y) = Student Satisfaction is described as follows (Figure 2).

This study is intended to reveal "what factors for information systems lecture (quality of information and quality of service) influence the students' satisfaction level". The targets of this research are active student at XYZ university (XYZ University has implemented ERP systems for operational and academic area). Data collection techniques: (1) the literature review; (2) The field research, the primary data were obtained through observations and questionnaires.

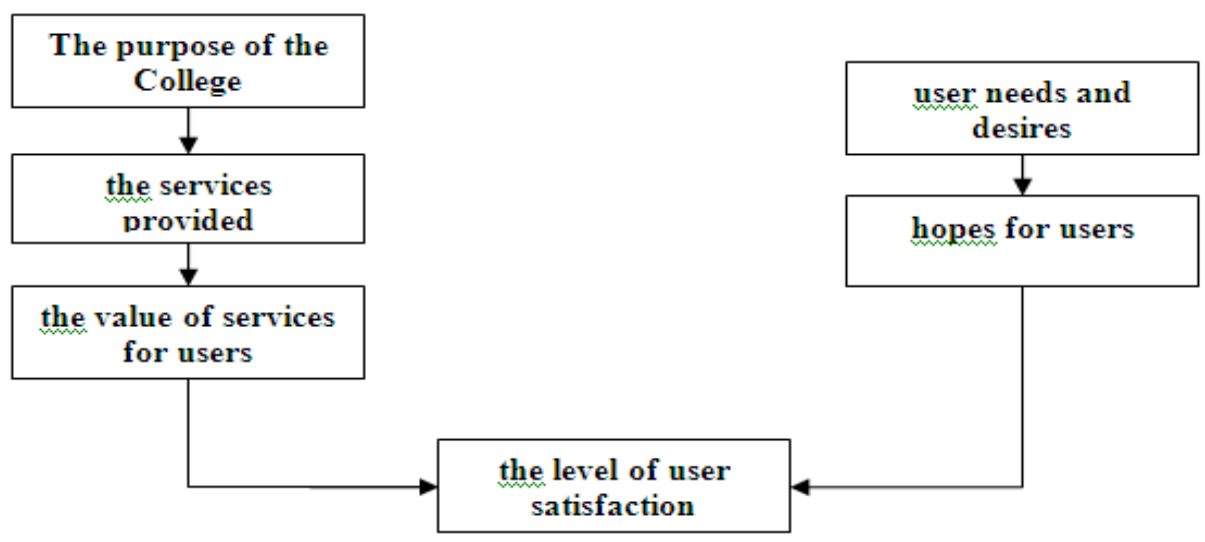

Fig. 1. The Concept of User Satisfaction [5]

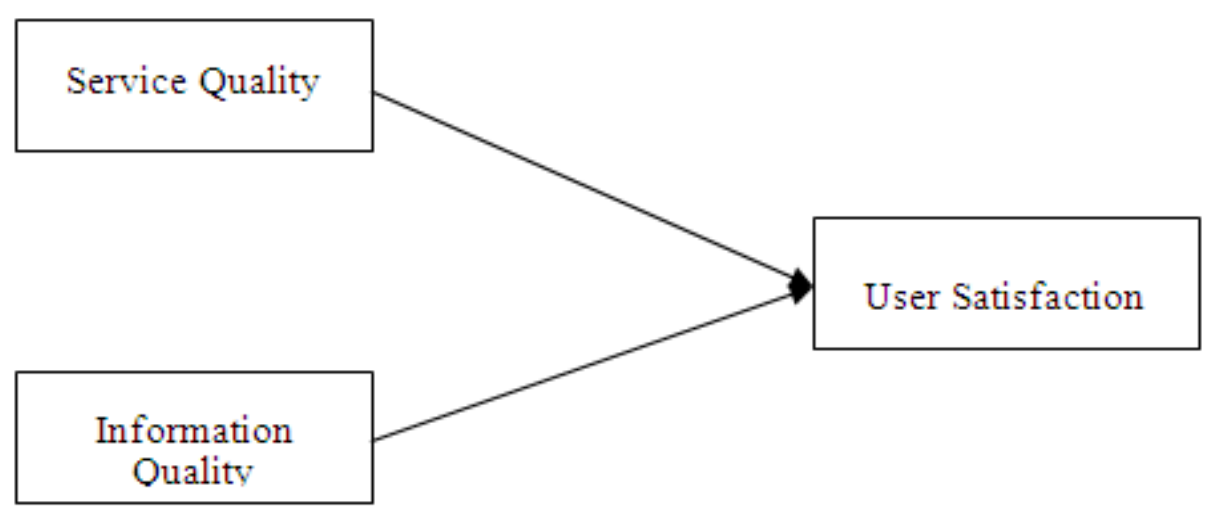

Fig. 2. The Model of User Satisfaction [6] 


\section{$3 \quad$ Results and Discussion}

The detailed questionnaires were distributed to students who were active at the university. The number of students was 392 respondents. Here are the results of the analysis given to the respondents, the student: (1) the name of the variable that measured satisfaction of students is "student satisfaction". It was used to measure the quality of services provided and the quality of information generated by the application; (2) the purpose of this analysis is to determine how the quality of service (X1), and the quality of information (X2) affect student satisfaction (Y). Statistical Package for the Statistical Sciences (SPSS) was used in data processing. The results of the variables tested employed multiple linear regression analysis, the quality of information (X1) as independent variable and student satisfaction (Y) as a dependent variable. Hypotheses for the quality of service are as follows:

\subsection{Hypothesis 1}

This hypothesis shows how the "quality of information" affects "student satisfaction". Table 1. shows the model summary.

Table 1. The Model Summary for Information Quality

Model Summary

\begin{tabular}{|l|r|r|r|r|}
\hline Model & R & R Square & $\begin{array}{c}\text { Adjusted } \\
\text { R Square }\end{array}$ & $\begin{array}{r}\text { Std. Error of } \\
\text { the Estimate }\end{array}$ \\
\hline 1 & $.692^{\mathrm{a}}$ & .479 & .475 & .54540 \\
\hline
\end{tabular}

a. Predictors: (Constant), Relevance, Accurate, Timeless

If the value of $\mathrm{R}$ is more than 0.5 , it will be considered a critical value. From the above table, it can be seen that the $\mathrm{R}$ value is 0.692 . It can be concluded that there is a relationship between dependent and independent variables. $\mathrm{R}$ Square has a value of 0.479 , which means the "quality of information" variable effect on "student satisfaction" as $47.9 \%$ and the rest is the other variables. From ANOVAs or F test, a value of 118.891 was obtained, with a significance level of 0.000 . Because the probability is less than 0.05 , then $\mathrm{H} 0$ and $\mathrm{H} 1$, it can be concluded that there is a relationship between the "qualities of information" simultaneously and "student satisfaction".

The t-test was used to determine the effect of independent variables individually against the dependent variable. If the value is less than $0.05(\mathrm{a}<0.05)$, then $\mathrm{H} 0$ is rejected and $\mathrm{H} 1$ is accepted. Regression equation:

$$
\mathrm{Y}=1,050+0,364 \mathrm{X}_{1}+0,219 \mathrm{X}_{2}+0,088 \mathrm{X}_{3}
$$

Where:

$\begin{array}{rll}\mathrm{Y} & = & \text { Student Satisfaction } \\ \mathrm{X}_{1} & = & \text { Accurate } \\ \mathrm{X}_{2} & = & \text { Timelines } \\ \mathrm{X}_{3} & = & \text { Relevance }\end{array}$


A constant value of 1.050 states that a third variable quality of the information has a value of 1.050. X1 regression coefficient (accurate) amounted to 0.364 states that any addition $(+) 1$ variable will increase student satisfaction by 0.364 . X2 regression coefficient (timelines) of 0.219 states that any addition $(+) 1$ variable of timelines will increase student satisfaction by 0.219 . Meanwhile, the regression coefficient X3 (relevance) of 0.088 states that any addition $(+) 1$ variable relevance will increase student satisfaction by 0.088 .s

Based on the table coefficient of multiple linear regression, it can be concluded that there is a positive effect of the use of information technology for improving the information quality of teaching and learning.

\subsection{Hypothesis 2}

This hypothesss shows the relationship between the quality of services and students' satisfaction. Table 2 presents the model summary.

Table 2. The Model Summary for Service Quality

\section{Model Summary}

\begin{tabular}{|l|r|r|r|r|}
\hline Model & $\mathrm{R}$ & R Square & $\begin{array}{c}\text { Adjusted } \\
\text { R Square }\end{array}$ & $\begin{array}{c}\text { Std. Error of } \\
\text { the Estimate }\end{array}$ \\
\hline 1 & $.645^{\mathrm{a}}$ & .416 & .408 & .57893 \\
\hline
\end{tabular}

a. Predictors: (Constant), Empathy, Tangible, Reliability, Assurance, Responsiveness

The value of $\mathrm{R}$ which is more than 0.5 will be considered a critical value. From the above table, it can be seen that the $\mathrm{R}$ value is 0.645 . It can be concluded that there is a relationship between the dependent variables and independent variables. $\mathrm{R}$ Square has a value of 0.416 for the relation between the service quality and student satisfaction.

Table 3. Analysis of Variance (ANOVA)

\section{ANOVR}

\begin{tabular}{|c|c|c|c|c|c|c|}
\hline Model & & $\begin{array}{l}\text { Sum of } \\
\text { Squares }\end{array}$ & df & llean Square & $\mathrm{F}$ & Sig. \\
\hline \multirow[t]{3}{*}{1} & Regressio & 92.139 & 5 & 18.428 & 54.982 & $.000^{\mathrm{a}}$ \\
\hline & Residual & 129.373 & 386 & .335 & & \\
\hline & Total & 221.512 & 391 & & & \\
\hline
\end{tabular}

a.Predictors: (Constant), Empathy, Tangible, Reliability, Assurance, F

From ANOVAs or F test, a value of 54.982 was obtained, with a significance level of 0.000 . Because the probability is less than 0.05 , then $\mathrm{H} 0$ and $\mathrm{H} 1$, it can be concluded that there is a relationship between quality of services and student satisfaction. Test ttest was used to determine the effect of independent variables individually against the 
dependent variable. If the value is less than 0.05 significant $(\mathrm{a}<0.05)$, then $\mathrm{H} 0$ is rejected and $\mathrm{H} 1$ is accepted.

Regression equation:

$$
\mathrm{Y}=0.880+0.011 \mathrm{X}_{1}+0.153 \mathrm{X}_{2}+0.146 \mathrm{X}_{3}+0.230 \mathrm{X}_{4}+0.205 \mathrm{X}_{5}
$$

Where, :

$\begin{array}{lll}\mathrm{Y} & = & \text { Student satisfaction } \\ \mathrm{X}_{4} & = & \text { Tangible } \\ \mathrm{X}_{5} & = & \text { Reliability } \\ \mathrm{X}_{6} & = & \text { Responsiveness } \\ \mathrm{X}_{7} & = & \text { Assurance }\end{array}$

For a constant value of 0.080 states that a third variable quality of the information, the student satisfaction has a value of 0.080 . X4 regression coefficient (tangible) of 0.011 states that any addition $(+) 1$ variable will increase student satisfaction by 0.011 . $\mathrm{X} 5$ regression coefficient (reliability) of 0.153 states that any addition $(+) 1$ variable timelines will increase student satisfaction by 0.153 .

X6 regression coefficient (responsiveness) of 0.146 states that any addition $(+) 1$ variable relevance will increase student satisfaction by 0.146 . X7 regression coefficient (assurance) amounted to 0.230 states that any addition $(+) 1$ variable assurance will increase student satisfaction by 0.230 . The regression coefficients X8 (empathy) of 0.205 states that any addition $(+) 1$ variable empathy will increase student satisfaction by 0.205 . Based on the coefficient of multiple linear regression, it can be concluded that there is a positive effect of the use of information technology in improving the service quality of teaching and learning process.

Further, based on the results of this research, the researchers give some recommendations with regard to the importance of information technology for student satisfaction. Information is important in the activities of universities/colleges. With the support of information technology, information can be more easily obtained without being limited by space and time. Information technology is designed to enable students at universities to record transactions and the information systems have many roles for helping people, namely: (1) solving problems, (2) increasing productivity, (3) improving the effectiveness, (4) increasing efficiency, and (5) improving creativity. Figure 3 shows the model to increase student satisfaction related to information technology.

Figure 3 presents a framework that describes the importance of attention to information and service quality as the foundation for designing information systems at universities. Service quality is more related to the interaction between users and information systems (media for distribution of information) at universities or we can associate this aspect with the human computer interaction area. Meanwhile, information quality is closely related to the management of data and information that exist in information systems owned by the universities. 


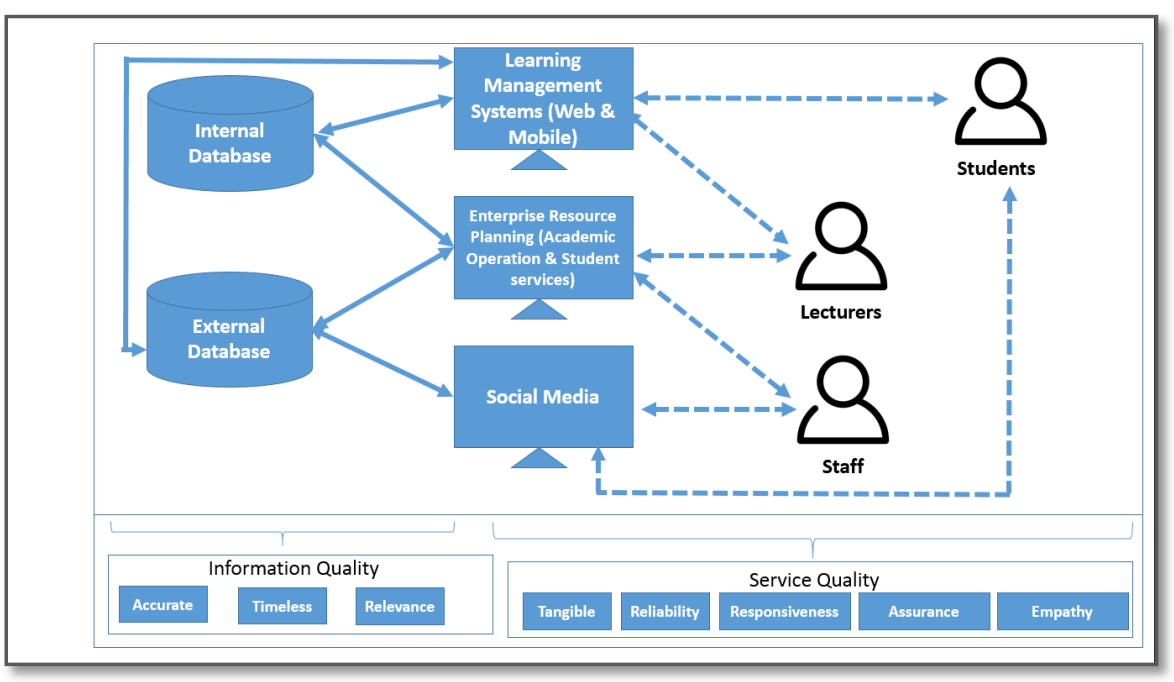

Fig. 3. The Model of Information Technology For University

\section{Conclusions}

Based on the research data, it can be concluded that: (1) there is a positive effect of the use of information technology in improving the information quality of teaching and learning at 0.454 . This is in line with the theory [7], that the use of information produced by the information system must be aligned with the users' needs. Further, the quality of information is highly dependent on the information system, which can be used to formulate strategies to help make decisions, comparisons, control operational activities (day to day activities / routines) and solve problems real time; (2) There is a positive effect of the use of information technology for improving the service quality of the learning process $(0.389)$, which is in line with the theory proposed by Lewis and Booms (1983), that the quality of services should be based on the needs of customers and end with satisfaction, as well as positive customers' perceptions of service quality.

\section{$5 \quad$ References}

[1] Hasan,Y., \& Shamsuddin,A., \& Aziati, N. (2013), The Impact of Management Information Systems adoption in Managerial Decision Making: A Review, The International Scientific Journal of Management Information Systems, Vol.8, No.4, pp. 010-017.

[2] Bin, W.,\& Chu-hong, Z., \& Qiong-yu, H.,\& Zhen-peng, L.(2010). Empirical Research on the Factor of ERP's User Customer Satisfaction Based on Triadic Reciprocal Determinism, International Conference on Management Science \& Engineering.

[3] Fathoni, 2009, Analisis Kualitas Layanan Sistem Informasi Menggunakan Metode Servqual, Konferensi Nasional Sistem dan Informatika, Bali : KNS \& I09-034

[4] Al-Mamary, Y.H., \& Shamsuddin,A., \& Nor Aziati, A.H. (2014) The Relationship between System Quality, Information Quality, and Organizational Performance, International Journal 
of Knowledge and Research in Management \& E-Commerce, Volume. 4, Issue 3, pp. 0710 .

[5] Parasuraman A. and Berry LL. (1990). Delivering Quality Service: Balancing Customer Perceptions and Expectations. New York, Macmillan.

[6] Caruana, A. (2002). Service loyalty. The effects of service quality and the mediating role of customer satisfaction. European Journal of Marketing, 36(7/8), 811-828. https://doi.org/10.1108/03090560210430818

[7] Al-hakim, L. 2007, Information quality management theory and applications idea group, inc

\section{Authors}

Lianna Sugandi is faculty member of the Bina Nusantara University (BINUS), Information Systems Department, School of Information Systems, Bina Nusantara University, Jakarta, Indonesia 11480She often works as academic operation center manager in Bina Nusantara University.

Yohannes Kurniawan is senior faculty member of the Bina Nusantara University (BINUS), Information Systems Department, School of Information Systems, Bina Nusantara University, Jakarta, Indonesia 11480. He often works as Publication Chair for several international conferences (ICIMTech and CHIuXiD) and is Head of Information Systems programs.

Article submitted 02 April 2018. Resubmitted 20 June 2018. Final acceptance 20 June 2018. Final version published as submitted by the authors. 